\title{
Does COVID-19 Change CSR? A Family Business Perspective
}

\author{
Elena Rivo-López ${ }^{1, *(\mathbb{D})}$, Mónica Villanueva-Villar ${ }^{2}$, Sofía Novoa-Santos ${ }^{3}$ and María Isabel Doval-Ruiz ${ }^{4}$ (D) \\ 1 Department of Business Organization and Marketing, Faculty of Business and Tourism, Universidade de \\ Vigo, 32004 Ourense, Spain \\ 2 Department of Financial Economics and Accounting, Faculty of Business and Tourism, Universidade de Vigo, \\ 32004 Ourense, Spain; monicavv@uvigo.es \\ 3 Independent Researcher, 32004 Ourense, Spain; sofia.novoa1@hotmail.com \\ 4 Department of Didactics Scholar Organisation and Research Methods, Faculty of Educational Sciences and \\ Social Work, Universidade de Vigo, 32004 Ourense, Spain; mdoval@uvigo.es \\ * Correspondence: rivo@uvigo.es
}

check for updates

Citation: Rivo-López, E.;

Villanueva-Villar, M.; Novoa-Santos, S.; Doval-Ruiz, M.I. Does COVID-19 Change CSR? A Family Business Perspective. Sustainability 2021, 13, 13954. https://doi.org/10.3390/ su132413954

Academic Editor: Maria I Marshall

Received: 6 November 2021

Accepted: 14 December 2021

Published: 17 December 2021

Publisher's Note: MDPI stays neutral with regard to jurisdictional claims in published maps and institutional affiliations.

Copyright: (c) 2021 by the authors. Licensee MDPI, Basel, Switzerland. This article is an open access article distributed under the terms and conditions of the Creative Commons Attribution (CC BY) license (https:// creativecommons.org/licenses/by/ $4.0 /)$.

\begin{abstract}
The purpose of this study was to analyze the \#Damos La Cara ("Let's show our face") initiative, which is an initiative promoted by the Instituto de la Empresa Familiar, the most representative organization of family businesses in Spain. This analysis allowed us to characterize the Spanish family business and to analyze their reactions and interventions in the face of the crisis posed by COVID-19 from the perspective of CSR. The methodology used consisted of a content analysis, viewing 127 videos wherein family members presented their companies and the activities carried out to improve their relations with their employees and their environment. The conclusions reached allowed us to affirm that they were mostly second- and third-generation companies from the manufacturing sector; the most repeated actions were social commitment to their workers (internal) and the donation of medical materials (corporate). To the best of our knowledge, this was the first time that an analysis of these characteristics had been carried out in the field of family businesses. This analysis showed the intense philanthropic activity carried out by Spanish family businesses, not only in emergencies but also as a regular activity and as a consequence of their values and long-term vision.
\end{abstract}

Keywords: corporate social responsibility; family business; COVID-19; crisis

\section{Introduction}

The literature on family businesses includes multiple definitions of the concept [1]. For instance, Christman et al. [2] identified 21 definitions of a family business (FB). Given this problem, the European Commission [3] has proposed the following as an official definition: "A company, of any size, is a family business, if: (a) Most of the decision rights are in the possession of the person who established the company, in the possession of the person who acquired the share capital of the company, or in the possession of their spouses, parents, children or direct heirs of the children; (b) They have the majority of decision rights, indirectly or directly; (c) At least one representative of the family or relative is formally involved in the governance of the company; (d) Listed companies can be defined as FB's if the person who established or acquired the company (share capital) or their families or descendants has $25 \%$ of the decision rights required by their share capital" [4] (p. 4).

The importance of family businesses worldwide is unquestionable in terms of the number of companies, their contribution to the GDPs of countries, and the volume of employment generated [5,6]. In Spain, $90 \%$ of private companies are family owned; these companies generate $70 \%$ of private employment and contribute nearly $60 \%$ of the GDP [7].

The COVID-19 pandemic collapsed the health system worldwide due to the large number of infections and greatly affected the economy due to the paralysis of economic activity as a result of confinement; confinement meant the temporary closure of establishments since only those sectors considered essential were allowed to open. According to the 
International Monetary Fund, the COVID-19 crisis represents one of the greatest challenges for the world economy [8]. In the case of the Spanish economy, the indicators for the first two months of 2020 showed GDP growth similar to that recorded in the previous quarters, which was around $0.4 \%$. There was also an increase in job creation in February of that same year, but the restrictions on activity that were established on 13 March 2020, caused a sharp decline in the indicators since the sectors that were most directly affected represented almost $15 \%$ of the GDP, including retail trade, restaurants, accommodation, cultural and sporting activities, and personal services. This caused a dragging effect of $6 \%$ of the GDP on the remaining sectors [9].

Long-term vision, responsibility, and commitment to the environment are core values of family businesses [10,11]. The global emergency caused by COVID-19 has posed a challenge for companies in general. This is especially true for family businesses, which are characterized, among other values, by trying to maintain employment in crises [12]. In this new emergency, they wanted to contribute to the sustainability of the system, not only from an internal point of view (via internal stakeholders: employees, customers, suppliers) but also externally, collaborating with society by offering both direct and indirect aid [6]. Sustainability practices can be defined as "those that work towards the longer term benefit of all of an organization's stakeholders-the broader community included" [13] (p. 26), which can be incorporated into a company's CSR. CSR is understood as "a concept whereby companies integrate social and environmental concerns in their business operations and in their interaction with their stakeholders on a voluntary basis" [14] (p. 8). Therefore, we can speak of such practices when there is favorable treatment of employees, fair treatment of customers, and charitable contributions to the community, which also benefit the company and all its stakeholders $[15,16]$.

Within the framework of family businesses in Spain, the Instituto de la Empresa Familiar (IEF) was created in 1992 with the 100 largest Spanish family businesses. It is a non-profit and independent business organization that, since its founding, has established itself as a benchmark in the business world by focusing on defending the interests of family businesses, identifying best practices in corporate governance and management, and ensuring the training of future generations. Subsequently, 18 regional associations were created, reaching a total of 1500 Spanish companies.

Within organizational communication, the following three fields are differentiated: corporate, internal communication, and external communication [17]. Corporate communication allows companies to differentiate themselves from the competition and maintain an emotional bond with customers. Internal communication is aimed at the employees of the company. Finally, external communication focuses on the company's products and tries to encourage their purchase [18]. In this study, we focused on internal and corporate communication, which are more strongly linked to CSR.

The communication strategy of the IEF, and of Spanish family businesses in general, is rather low profile. Each company publicizes its activity, but in most cases without linking it to the owner family. The situation caused by COVID-19 led to a radical change in many aspects, including communication, since the pandemic changed the perception of the use of communication channels [19]. Thus, Spanish family businesses, supported by their regional associations, decided to use the Internet as a communication channel [20] and to promote the campaign \#Damos la Cara. Through the web page www.damoslacara.com, accessed on 5 November 2021, family entrepreneurs present their family history and their way of facing the crisis in short videos of about two minutes. They also present the various corporate responsibility activities they decided to carry out in order to cooperate with the various stakeholders due to the situation caused by COVID-19. Therefore, as we mentioned earlier, although we focused on internal and corporate communication, this also involved external communication, since it allows potential buyers to get to know the companies and, therefore, the products they offer.

Although sustainability is a widely debated topic, the research on sustainability in the context of family businesses is not very extensive. Sustainability practices affect a 
company's reputation, both in the short and long term. Therefore, taking into account the importance that FBs give to sustainability and, in turn, the relevance of these companies in the global economy, the study of both topics is becoming increasingly relevant [4] (p. 1). Our contribution is to reinforce the previous literature on sustainability with a novel study. To the best of the authors' knowledge, this is the first piece of research that analyzed communication and sustainability that was focused on family businesses. The goal of this research was to analyze the content of this campaign, identify the different business and family profiles, and identify the different actions of Spanish family businesses in terms of CSR. This analysis showed the intense philanthropic activity carried out by Spanish family businesses, not only in emergencies but also as a regular activity in their history and as a consequence of their values and long-term vision.

\section{Materials and Methods}

During the COVID-19 pandemic, the citizens' movement, Damos La Cara, was created to demonstrate the commitment of workers and businesspeople to their suppliers, customers, and society. In this way, it was possible to show the important work carried out by each of the Spanish family businesses, demonstrating their economic and social commitments. They were also committed to promoting the entrepreneurial spirit of the new generations, who are a fundamental pillar in society's recovery [21].

In the media presentation of the "Damos la cara" campaign, Marc Puig, the president of the Instituto de la Empresa Familiar and CEO Puig, made the following statement: "The concern of family businesses has been that of survival, paying the payroll. Now that the measures and credits are starting to work, the concern is to maintain jobs and think about how to take advantage of this crisis as an opportunity."

On its website, the Damos La Cara initiative [22] explains some of the reasons why they carried out this project: $89 \%$ of companies in Spain are family owned, generating $67 \%$ of private employment in the country; family businesses contribute $57.1 \%$ of the Spanish GDP; and the average longevity of a family business is 33 years, while that of a non-family business is 12 years.

This movement arose under the proposal of several Territorial Associations of Family Businesses in Spain at the beginning of the COVID-19 pandemic; they considered that it would be a good idea to make all those actions carried out by family businesses visible in order to show the support provided by this type of company to society in times of health and economic crises [23]. The companies participating in this campaign have shown the histories of their companies and the difficulties they have had to overcome over the years through short videos. Several of these companies have a long history, having been present during the First and Second World Wars, the Spanish Civil War, and the Financial Crisis of 2008, among other events, such as fires and floods; therefore, it was not the first time that many of these companies had faced a crisis.

Through their videos, the companies show their business activity and its development, their daily activities, and how they have had to reorganize their workplaces in order to adapt them to teleworking or, if this was not possible, to adopt the necessary safety measures to protect workers. In these videos, the entrepreneurial families show their long-term vocation and commitment to the business project and their workers, presenting the CSR activities they carry out. Many of them comment that "the family business is not the inheritance we receive from our parents, it is the loan that our children make to us," referring to the long-term commitment and the intention to maintain a company through the years from generation to generation, for which they have done their best to ensure the continuity of the company.

The proposed methodology was based on video content analysis, a methodology used in other analyses of viral advertising campaigns [24]. In total, 127 company videos were found on the Damos La Cara campaign website at the time of analysis (June 2021), with an average duration of two minutes each. Once the videos had been viewed, data were 
collected on the name of the family business, the family of origin, its generation, the sector to which it belonged, and the CSR activities it carried out.

\section{Results and Discussion}

\subsection{Generation}

According to the IEF, $43 \%$ of family businesses were in the second generation, only $9 \%$ of them were in the third generation, and only $1 \%$ were in the fourth generation [25]. In the case of the family businesses participating in the Damos La Cara initiative, there were companies in the first to the eighth generation of the family.

As can be seen in Figure 1, the participating companies were mainly in the second family generation, representing $44 \%$ of the total, followed by third-generation companies, which represented $29 \%$. The percentage started to decrease from the third and subsequent generations.

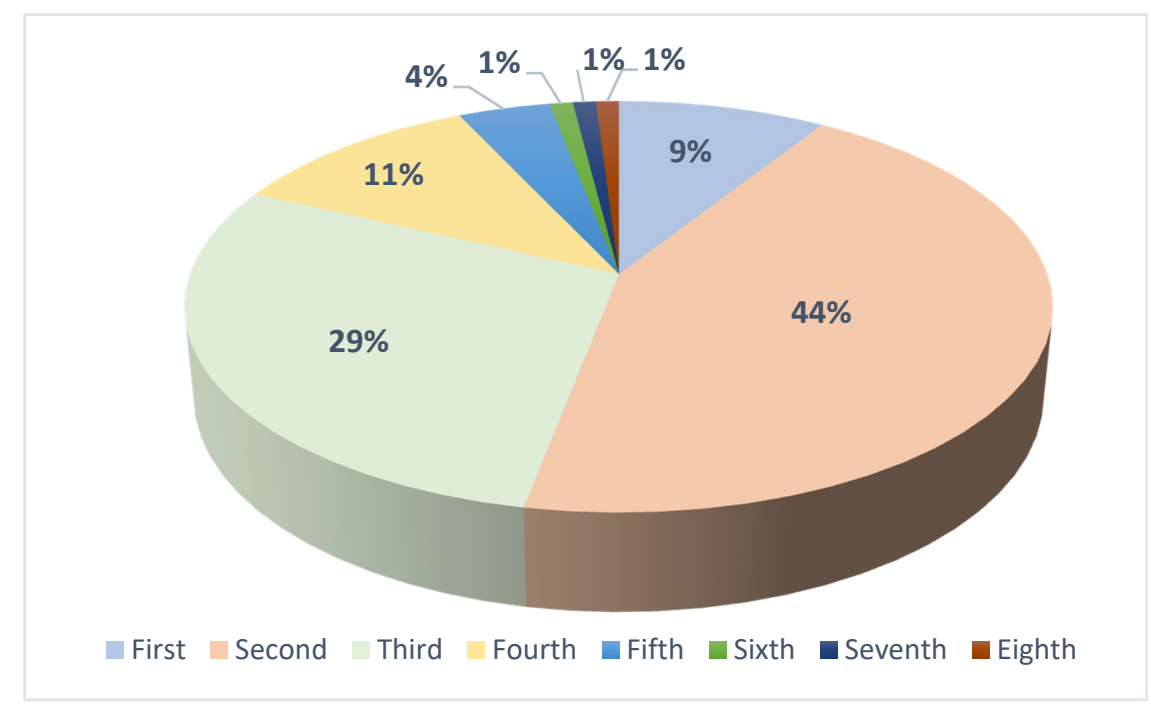

Figure 1. Family generation in which the family businesses participating in the Damos La Cara initiative were found. Source: own elaboration.

Of the companies analyzed, the Osborne Group stood out because it is a company that is in its eighth generation of the family, with almost 250 years of history. This business group is responsible for the production of wines, spirits, and pork products. During the beginning of the COVID-19 pandemic, the Osborne Foundation donated $200 \mathrm{~kg}$ of medical material to China, including more than 2400 masks and 38,000 pairs of latex gloves [26]. Then, when the pandemic reached Spain, they launched an encouraging message to society by labeling the iconic Osborne Bull under the slogan \#ConEstoTambiénPodremos (\#WithThisWeWillAlsoBeAble). When the state of alarm was declared in Spain, Osborne made its distilleries and workers available to the government to produce sanitary alcohol, which was in short supply. They also carried out various actions, such as disinfecting the streets of Malpica de Tajo in Toledo, creating educational and entertainment content, and providing online training for those interested in entering the labor market [23].

\subsection{Business Sector}

From studying the sectors in which the companies carried out their activities, it can be seen that, of the companies that participated in this campaign, $40 \%$ belonged to the manufacturing industry, followed by $20 \%$ in wholesale and retail trade, and $8 \%$ in hotels and catering (Figure 2). 


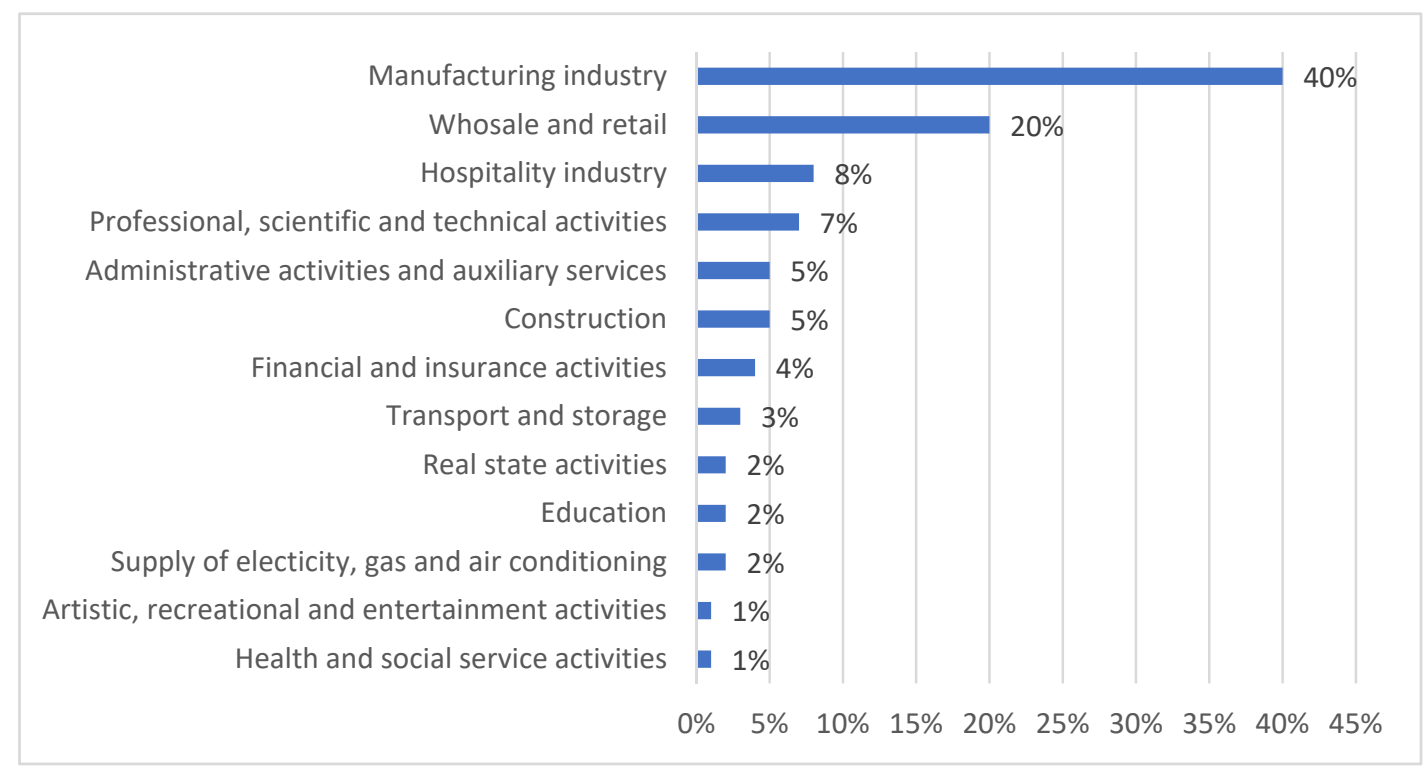

Figure 2. Sectors of activity of the family businesses participating in the \#Damos La Cara campaign. Source: own elaboration.

The manufacturing industry includes sectors such as meat and poultry products, soap, detergents, and other cleaning and polishing products, i.e., sectors that manufacture foodstuffs, electrical components, and various other products. In most of these sectors, they were working continuously from the beginning of the state of alarm to ensure that nothing was missing in any home or that the basic services were working. This was also the case in the wholesale and retail trade, with the main intermediaries working to ensure that products reached their customers.

The hotel sector, on the other hand, has been one of the hardest hit, along with construction, education, entertainment, etc., by the pandemic. The confinement made many establishments close; others had to stop projects and adapt their technology. There were also sectors that, due to their characteristics, could not telework.

\subsection{CSR Activities}

Figure 3 shows the main actions carried out by family businesses during the COVID-19 pandemic that were commented on in the videos of the Damos La Cara initiative. As can be seen, social commitment to their workers was the most repeated action by the companies that participated in this initiative. In most of the videos, the business families affirmed their great commitment to maintaining the jobs of their employees, and they sought to reconcile the work and family lives of their workers in such difficult times through flexible working hours and the implementation of teleworking for those jobs where it was possible to implement it. Additionally, many of the companies avoided using the ERTE scheme for their workers; those that saw the need to do so, due to the type of activities they carried out, on many occasions made an advance payment to the workers who were waiting a long time to be paid through the ERTE.

Other companies opted to negotiate with their workers, such that the members of the company with higher salaries accepted a reduction in their salaries in order to compensate or maintain the salaries of workers with lower salaries. Other companies also opted to advance their workers' bonus payments. All the companies were concerned about the safety of the workers, carrying out antigen tests when they returned to their jobs, ensuring safe distances, and providing them with the necessary sanitary material for their protection.

The donation of sanitary material was the second most repeated action by the family companies. Donations of PPE, face shields, masks, hydroalcoholic gel, and bleach, among other things, were made to hospitals, old people's homes, town halls, and workers' families. Companies such as Aciturri, which have 3D printers, used them to manufacture masks, PPE, and the components needed for respirators; other companies, such as Jamones Tartessos 
and Symaga, donated materials from their facilities, such as disposable gloves, overalls, and tights, to the public health system.

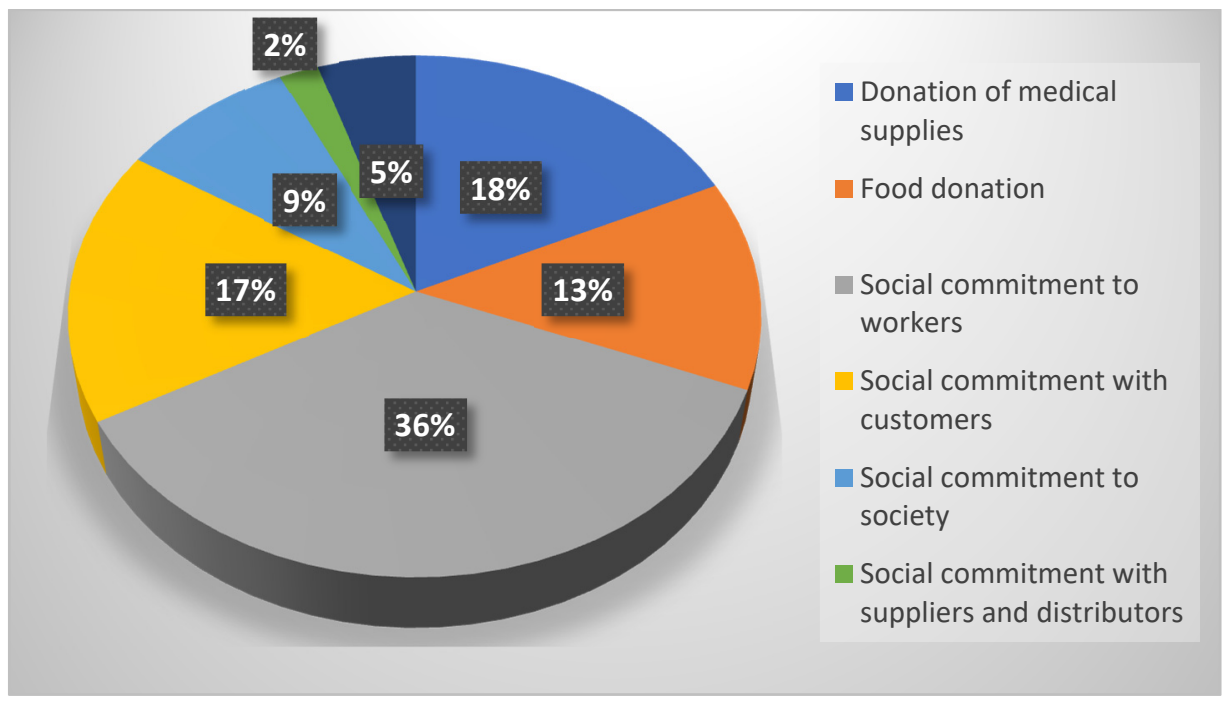

Figure 3. Sectors of activity of the family businesses participating in the \#Damos La Cara campaign. Source: own elaboration.

Of the largest family-owned companies in Spain ranked by 2017 revenues, Corporación Gestamp was, for that year, in fifth position in the ranking; in their video, they mention donating sanitary materials to hospitals, 3D printing parts needed for the production of protective face shields, and donating cell phones so that cardiology patients in the "Unidos por el Corazón" ("United by Heart"). Program of the Ramón y Cajal Hospital could communicate with their relatives.

Family businesses also demonstrated a strong social commitment to their customers. Among the various actions they carried out, they sent messages of encouragement to their customers through social networks or when they made a purchase, tried to maintain adequate protection measures to prevent customers from being infected in stores as they made their purchases, and in other cases, they gave discounts and offered payment plans to those customers who could not afford items for various reasons.

Many companies stood out for helping their clients through the sector in which they operated. In the case of Gesa Mediación, they launched the campaigns "Si estás cubierto" ("If you're covered") and "Expertos a tu disposición" (Experts at your disposal) through social networks and the media to assuage their clients' doubts about their insurance coverage. Grupo Antón Comunicación offered a free consultancy service to analyze the new scenario that companies were facing in order to help them achieve their objectives, while ESOC provided free specific training to all its clients on the protocols, procedures, and measures required for COVID-19.

The donation of food was another of the actions carried out by the family businesses in the face of the COVID-19 pandemic. Most of the companies made donations of products that they sell; for example, the company PROSOL, which produces and sells coffee, made a donation of coffee to the hospitals of Palencia for the health personnel to consume during their rest periods; other companies, such as Santo Tomé, donated sweets for the health personnel of the hospitals in Toledo; Cárnicas Iglesias donated sausages to different hospitals around the country; and a large number of companies donated food to the Red Cross, Caritas, the Food Bank, and town halls, among others.

Family businesses also demonstrated a great social commitment to society by creating jobs and by sending messages of encouragement and thanks to all the professionals who were working on the front line during the confinement. Companies in the transport sector 
were in charge of transporting medical supplies and food, and other companies made themselves available to their local councils to help with whatever was necessary.

Companies such as Tous stood out for their participation in special festivities, such as Mother's Day, when they gave vouchers to the mothers of newborns to be exchanged for a gift in their stores; Rialto distributed chocolate figures for children at Easter; and Torrons Vicens donated 50,000 bars of nougat to the Food Banks at Christmas under the slogan "No home without nougat."

Among the actions carried out by these family companies, it is also worth mentioning the transfer of lodgings and vehicles. Palladium Hotel Group ceded one of its hotels located next to the Gregorio Marañón Hospital to be medicalized; other hotels ceded their facilities to caregivers of nursing homes, to COVID-19-positive health personnel, or to accommodate health personnel and state security forces living with people at risk. In the case of the transfer of vehicles, companies such as Domingo Alonso and Unsain Group gave their vehicles free of charge for the transport of food and sanitary material and for medical personnel with difficulties traveling to their workplaces.

Finally, in the videos of this initiative, the family-owned companies also mentioned the social commitment they have maintained with their suppliers and distributors since, in many cases, they made advance payments to the most vulnerable suppliers and also offered longer payment terms to their distributors.

In short, family businesses sought to overcome the crisis posed by the pandemic through innovation $[27,28]$. One of the ways they achieved this was by changing how they communicate with their environment [29], producing a shift toward digital channels, where the importance of communicating CSR practices through these channels became fundamental [30]. Family support and social networks are criteria that affect decisions to be innovative [31].

\section{Conclusions}

Resilience, agility, and adaptability are some of the characteristics that have defined family businesses during the pandemic and have enabled them to meet the challenges they have faced during these difficult times. The COVID-19 pandemic has tested the resilience of family businesses, as they have had to adapt their business plans to cope with mobility restrictions, paralyzed supply chains, declining consumption in certain sectors, and loss of customer confidence. Due to the uncertainty generated by the pandemic, in October 2020, when the second wave caused the implementation of new restrictions, Spanish family business revenues decreased by $63 \%$ compared to the levels registered prior to the pandemic; $24 \%$ of the companies managed to maintain their sales, and $12 \%$ of the family businesses experienced an increase for various reasons, such as the adaptation of their products to the online environment, as well as adaptation to the health crisis and the new needs of the market [25]. On the other hand, a positive image of a firm regarding CSR can even lead to more sales and investments [32].

The aim of this research was to analyze the collaboration of family businesses in crises, focusing the analysis on the actions carried out to alleviate the consequences of the COVID-19 pandemic. The IEF promoted the \#Damos La Cara campaign in which family businesses from all over Spain, from the smallest to the giants, explained their activities, their values, and their CSR actions in support of their employees, clients, suppliers, and society during the economic and health crisis in a video. The campaign, as Fernando Rodés (ISP CEO) explains, "has been bottom-up, the institute has only conveyed people's desire to explain themselves" and has already garnered 11 million unique users. The campaign, as Francisco J. Riberas (CEO of Gestamp, a multinational automotive components company) explains, also arose as a positive reaction to a crisis that will last a few years and has already had a strong impact on some sectors; along with the rest of the industry, Gestamp has suffered from the downturn.

It is noteworthy that most of the family businesses that joined this initiative are in the second generation of the family, representing $44 \%$ of all the participating companies. 
Family businesses tend to be involved in long-term projects since their objective is to maintain the company through the years, from generation to generation. In terms of each sector's activity, the manufacturing industry is the one that has participated the most in this campaign.

In the past Spanish economic crisis of the 2007-2013 period, Spanish family businesses maintained more employment than non-family businesses [8]. This shows a greater commitment and responsibility on the part of family businesses to preserving jobs, even in extreme crises. This situation has been repeated in this latest crisis, which was suffered as a result of COVID-19. From the analysis of the videos of the \#Damos La Cara initiative, it was concluded that the most repeated action by family businesses was fulfilling their social commitment to their workers. They were concerned about their safety, trying to maintain all the necessary measures to avoid the contagion, avoiding temporary layoffs, implementing teleworking in all the jobs that allowed it, worrying about the work-life balance of their workers, and allowing flexible working hours; in many cases, they also advanced extra pay or reduced the salaries of the managers and salaried staff of the company in order to ensure payment of the rest of the workers' salaries. In any case, the family businesses were committed to maintaining jobs and, in some cases, even promoted job creation in the midst of a situation of great uncertainty.

During this crisis, family-owned companies made donations of sanitary materials and food, both for health personnel and for the rest of society through town councils, the Food Bank, Caritas, and the Red Cross, among other charitable organizations. Many of the companies made donations of the products that they produce and sell, and in other cases, they used their companies' machinery for the manufacture of hydroalcoholic gels, masks, facial protection screens, and parts for hospital respirators, among others. Companies in the hotel sector lent their hotels to be medicalized or to house health personnel living with people at risk or nurses in old people's homes.

This study confirmed the great social commitment of family businesses to maintaining the welfare of society and the continuity of the company in emergencies, in line with García-Sánchez and García Sánchez [31]. Mariani et al. [32] stated that FBs are more likely to invest in and be more engaged with CSR practices than non-family businesses.

Entrepreneurs and workers have promoted a movement to try to enhance the perceived value of these companies since they are often reviled by society and the political class despite being the most committed during crises. Perhaps the challenge for the future will be to achieve this positive vision of businesses and their corporate social responsibility activities in times of normality.

\section{Theoretical and Practical Implications}

This study can be a useful reference for future academic and business studies focused on CSR policymaking and communication strategies through digital media. First, the study contributes to the literature on sustainability and family business communication. From a management point of view, entrepreneurs will be able to consider the elaboration of short videos to present their companies and their CSR dynamics as part of their business strategy. In addition, this campaign, which was promoted in Spain by the Family Business Institute, can serve as a reference and be replicated by family business associations in other countries.

Finally, although this study focused on family businesses, it can be used as a reference for the communication and CSR strategies of non-family businesses. The background of the campaign is to value the concept of entrepreneurs and their contribution to society through their CSR activities.

\section{Limitations and Research Agenda}

We should not conclude this paper without pointing out this study's main limitation, which was its focus on a single country. On the other hand, new research based on a competitive-action perspective [33] or the theory of dual responsibility [34] has recently shown that companies that exercise dual responsibility (non-social and social) achieve better performance. For family firms, this may even be more important given their need to 
establish both an economic reputation (competitive) and a social reputation that would earn them support and legitimacy.

In this sense, future research should study the relationship between CRS and corporate financial performance by analyzing the differences between family and non-family firms. It would also be interesting for future research to analyze the communication campaigns carried out in other countries, if any exist; this would allow us to compare the types of CSR activities carried out and to identify any coincidence in the characterization of family businesses.

Author Contributions: Conceptualization, E.R.-L. and M.V.-V.; methodology, E.R.-L. and M.V.-V.; investigation, S.N.-S. and M.I.D.-R.; writing—original draft preparation, S.N.-S.; writing—review and editing, E.R.-L. and M.V.-V.; supervision, M.I.D.-R. All authors have read and agreed to the published version of the manuscript.

Funding: This research received no external funding.

Conflicts of Interest: The authors declare no conflict of interest.

\section{References}

1. Fonseca, A.P.; Carnicelli, S. Corporate Social Responsibility and Sustainability in a Hospitality Family Business. Sustainability 2021, 13, 7091. [CrossRef]

2. Christman, J.J.; Chua, J.H.; Sharma, P. Defining the family business by behaviour. Entrep. Theory Pract. 1999, 23, 19-39.

3. European Commission. Final Report of the Expert Group-Overview of Family-Business; Relevant Issues: Research. Networks, Policy Measures and Existing Studies; European Commission: Brussels, Belgium, 2009.

4. Curado, C.; Mota, A. A Systematic Literature Review on Sustainability in Family Firms. Sustainability 2021, 13, 3824. [CrossRef]

5. Astrachan, J.H.; Shanker, M.C. Family businesses' contribution to the U.S. economy: A closer look. Fam. Bus. Rev. 2003, 16, 211-219. [CrossRef]

6. Rivo-López, E.; Villanueva-Villar, M.; Michinel-Álvarez, M.; Reyes-Santías, F. Corporate social responsibility and family business in the time of COVID-19: Changing strategy? Sustainability 2021, 13, 2041. [CrossRef]

7. Instituto de la Empresa Familiar. Available online: https://www.iefamiliar.com/asociaciones-territoriales/ (accessed on 12 October 2021).

8. IMF. Annual Repport. Available online: https://www.imf.org/external/pubs/ft/ar/2020/eng/ (accessed on 13 September 2021).

9. Torres, R.; Fernández, M.J. Se inicia la recuperación, pero persisten las incertidumbres. Cuad. Inf. Econ. 2020, 277, 1-8.

10. Astrachan, C.B.; Botero, I.; Astrachan, J.H.; Prügl, R. Branding the family firm: A review, integrative framework proposal, and research agenda. J. Fam. Bus. Strategy 2018, 9, 3-15. [CrossRef]

11. Binz, C.A.; Ferguson, K.E.; Pieper, T.M.; Astrachan, J.H. Family business goals, corporate citizenship behaviour and firm performance: Disentangling the connections. Int. J. Manag. Enterp. Dev. 2017, 16, 34-56. [CrossRef]

12. Rivo-López, E.; Villanueva-Villar, M.; Vaquero-García, A.; Lago-Peñas, S. Do family firms contribute to job stability? Evidence from the great recession. J. Fam. Bus. Manag. 2020. [CrossRef]

13. Le Breton-Miller, I; Miller, D. Family firms and practices of sustainability: A contingency view. J. Fam. Bus. Strategy 2016, 7, 26-33. [CrossRef]

14. European Commission. Directorate-General for Employment. Promoting a European Framework for Corporate Social Responsibility; Office for Official Publications of the European Communities: Brussels, Belgium, 2001.

15. Hart, S.L.; Milstein, M.B. Creating sustainable value. Acad. Manag. Perspect. 2003, 17, 56-67. [CrossRef]

16. Carroll, A.B.; Buchholtz, A.K. Business and Society: Ethics, Sustainability, and Stakeholder Management; Cengage Learning: Boston, MA, USA, 2014.

17. Enrique, A.M. La Planificación de la Comunicación Empresarial; Universitat Autònoma de Barcelona: Barcelona, Spain, 2008; Volume 202.

18. Mata, P.; Buil, T.; Gómez-Campillo, M. COVID-19 and the reorientation of communication towards CSR. Econ. Res.-Ekon. Istraž. 2021, 1-21. [CrossRef]

19. Broccardo, L.; Truant, E.; Zicari, A. Internal corporate sustainability drivers: What evidence from family firms? A literature review and research agenda. Corp. Soc. Responsib. Environ. Manag. 2019, 26, 1-18. [CrossRef]

20. Erjavec, K.; Janžekovič, M.; Kovač, M.; Simčǐč, M.; Mergeduš, A.; Terčič, D.; Klopčič, M. Changes in Use of Communication Channels by Livestock Farmers during the COVID-19 Pandemic. Sustainability 2021, 13, 10064. [CrossRef]

21. La Cara, D. Iniciativas Apasionantes. Available online: https://www.damoslacara.com/iniciativas-apasionantes/ (accessed on 15 June 2021).

22. La Cara, D. Quiénes Somos. Available online: https://www.damoslacara.com/quienes-somos/ (accessed on 15 June 2021). 
23. Instituto de la Empresa Familiar. Las Empresas Familiares Impulsan el Movimiento \#DamoslaCara. 11 de junio de 2020. Available online: https:/ / www.iefamiliar.com/noticia/las-empresas-familiares-impulsan-el-movimiento-damoslacara/ (accessed on 25 June 2021).

24. Gómez, A.D. The key elements of viral advertising. From motivation to emotion in the most shared videos. Comunicar. Media Educ. Res. J. 2014, 22, 199-207. [CrossRef]

25. Instituto de la Empresa Familiar, KPMG \& STEP Project. Informe de Empresa Familiar 2021. 2021. Available online: https: //assets.kpmg/content/dam/kpmg/es/pdf/2021/06/informe-empresa-familiar-2021.pdf (accessed on 25 June 2021).

26. La Vanguardia. Fundación Osborne Dona 200 Kilos de Material médico Para Luchar Contra el Coronavirus en China. Available online: https:/ / www.lavanguardia.com/vida/20200304/473964629346/economiaempresas-fundacion-osborne-dona-200-kilosde-material-medico-para-luchar-contra-el-coronavirus-en-china.html (accessed on 14 July 2021).

27. Erdogan, I.; Rondi, E.; De Massis, A. Managing the tradition and innovation paradox in family firms: A family imprinting perspective. Entrep. Theory Pract. 2020, 44, 20-54. [CrossRef]

28. Jabeen, F.; Faisal, M.N.; Al Matroushi, H.; Farouk, S. Determinants of innovation decisions among Emirati female-owned small and medium enterprises. Int. J. Gend. Entrep. 2019, 11, 408-434. [CrossRef]

29. Xifra, J. Comunicación corporativa, relaciones públicas y gestión del riesgo reputacional en tiempos del COVID-19. Prof. Inf. 2020, 29, 2. [CrossRef]

30. Al-Esmael, B.; Talib, F.; Faisal, M.N.; Jabeen, F. Socially responsible supply chain management in small and medium enterprises in the GCC. Soc. Responsib. J. 2019, 16, 369-386. [CrossRef]

31. García-Sánchez, I.M.; García-Sánchez, A. Corporate social responsibility during COVID-19 pandemic. J. Open Innov. Technol. Mark. Complex. 2020, 6, 126. [CrossRef]

32. Mariani, M.M.; Al-Sultan, K.; De Massis, A. Corporate social responsibility in family firms: A systematic literature review. J. Small Bus. Manag. 2021, 1-55. [CrossRef]

33. Kim, K.-H.; Kim, M.; Qian, C. Effects of Corporate Social Responsibility on Corporate Financial Performance: A CompetitiveAction Perspective. J. Manag. 2018, 44, 1097-1118. [CrossRef]

34. Al-Shammari, M.A.; Banerjee, S.N.; Rasheed, A.A. Corporate social responsibility and firm performance: A theory of dual responsibility. Manag. Decis. 2021. ahead-of-print. [CrossRef] 